\title{
Guerra declarada e paz fingida na Restauração Portuguesa ${ }^{* * *}$
}

\author{
Ronaldo Vainfas ${ }^{* * *}$
}

\author{
O imperfeito é o tempo da fascinação: \\ parece vivo e no entanto não se mexe. \\ Presença imperfeita, morte imperfeita. \\ Nem esquecimento nem ressurreição. \\ Simplesmente o cansativo engano da memória. \\ (Roland Barthes, 1977)
}

O artigo analisa o conflito diplomático entre Portugal e Países Baixos, no contexto da Restauração, relacionado às guerras holandesas em Pernambuco durante o século XVII. A principal discussão está baseada no Papel Forte, escrito por Antônio Vieira, no qual o jesuíta defendeu que Portugal devia renunciar às capitanias açucareiras do nordeste brasileiro para evitar uma nova guerra na Europa. Uma guerra que, para ele, seria desastrosa para o fortalecimento da dinastia de Bragança contra a Espanha. Palavras-chave: Restauração Portuguesa - Guerras Pernambucanas - Papel Forte

*A base deste artigo é a comunicação inédita que apresentei no II Colóquio Internacional da Companhia das Îndias/PRONEX, Império de várias faces, realizado na UFF, em março de 2007. O texto original foi acrescido de considerações sobre a conjura nobiliárquica contra D. João IV, em 1641, e sobre o Papel Forte, de Antônio Vieira, escrito entre o fim de 1648 e o início de 1649. Este último tópico foi matéria de palestra proferida em Lisboa, em outubro de 2008, no Congresso Internacional Vieira - o tempo e os seus hemisférios, realizado na Universidade Nova de Lisboa. Nessa ocasião, tive a felicidade de encontrar várias vezes com Fátima, amiga de mais de 30 anos, sem saber que tais encontros eram os últimos. Dedico este texto a Fátima, com muita saudade.

** Artigo recebido e aprovado para publicação em junho de 2009.

*** Professor titular de História Moderna da Universidade Federal Fluminense. E-mail: rvainfas@terra.com.br. 


\section{Declared war and feigned peace in Portuguese Restoration}

The article analyses the diplomatic conflict between Portugal and the Netherlands in the context of the Restoration related to the Dutch wars in Pernambuco during the XVII century. The main discussion is based on Papel Forte, written by Antonio Vieira, in which the Jesuit maintained that Portugal had to renounce to the sugar captaincies in the northeast of Brazil to prevent a new war in Europe. A war that, according to him, would be disastrous for the strengthening of the Bragança dinasty against Spain.

Keywords: Portuguese Restoration - Pernambuco Wars - Papel Forte

Guerre déclarée et simulacre de paix pendant la Restauration Portugaise L'article analyse le conflit diplomatique entre le Portugal et les Pays-Bas dans le contexte de la Restauration liée aux guerres hollandaises à Pernambuco pendant le XVII siècle. La discussion principale porte sur l'ouvrage Papel Forte, écrit par Antônio Vieira, dans laquelle ce jésuite soutient que le Portugal devait renoncer aux capitaineries sucrières dans le Nord-Est brésilien pour éviter une nouvelle guerre en Europe, une guerre qui, selon lui, serait désastreuse pour la consolidation de la dynastie Bragança contre l'Espagne.

Mots-clés: Restauration Portugaise - Guerres Pernambucaines - Papel Forte

\section{Guerra ou paz: os impasses de 1648}

"É melhor ter com eles (holandeses) guerra declarada do que paz fingida”. Foi o que escreveu Manoel de Moraes, em outubro de 1648, emitindo um dos mil pareceres que o hesitante rei D.João IV solicitava aos que tinham experiência em assuntos holandeses. ${ }^{1}$ Era tempo de pareceres solicitados pelo rei sobre se convinha ou não ceder o Brasil às Províncias Unidas dos Países Baixos em troca da paz. Aliás, como escreveu Evaldo Cabral de Mello, em $O$ negócio do Brasil, quem hoje compulsa os códices seiscentistas nas bibliotecas

\footnotetext{
${ }^{1}$ A "Resposta aos holandeses" foi descoberta por Eduardo Prado na Seção de Manuscritos da Biblioteca Nacional de Lisboa, Códice 1551, fls. 59-63. Eduardo Prado fê-la copiar na íntegra, sendo o texto mais tarde publicado por Afonso de Taunay nos Anais do Museu Paulista, São Paulo, tomo I, 1922, p. 119-143. Há outra cópia do mesmo documento na Seção de Manuscritos da Biblioteca Nacional de Lisboa, Códice 2694, fls. 37-42.
} 
e arquivos portugueses "topa invariavelmente com manuscritos sobre as paæes da Holanda". 2

O texto de Manoel de Moraes apresenta os ingredientes de um parecer formal sobre a questão. Manoel se dirigiu ao rei: "Isto escrevo como fiel vassalo de Sua Majestade, como quem correu todas aquelas terras, tratou todas aquelas gentes, e lhes conhece de experiência as condições" - texto oficial e segredo de Estado: "sob censura". Sendo o assunto a famigerada "paz com a Holanda, Manoel começa o texto louvando a paz, enquanto princípio, nela vendo a raiz da prosperidade dos povos; mas não a paz com os holandeses, dizia, que eram povos "variáveis, inquietos e mal intencionados". Só fazem a paz enquanto lhes convêm - acrescentou - e ao menor descuido "quebram as leis dela". O mote do seu texto se pode resumir no argumento citado no início: "é melhor ter com eles (holandeses) guerra declarada do que paz fingida".

Manoel refutou, portanto, o que considerava os quatro pontos essenciais do tratado "entreguista" que Portugal negociava com os holandeses, afirmando que na Europa, se fosse possível, a paz era bem-vinda. Mas no sul, isto é, no Brasil, somente a guerra resolveria o impasse. Considerou inaceitável que Portugal cedesse aos holandeses território tão rico em engenhos de açúcar, tabaco, pau-brasil e mantimentos variados. Alegava que Portugal não precisava da Holanda para nada, pois tudo que vendiam no Brasil vinha de outras partes: a aguardente da França, as munições da Dinamarca ou Hamburgo, o ferro da Suécia. Em contrapartida, a Holanda não podia viver sem o sal de Setúbal e sem a riqueza do Brasil. Considerou também absurda a exigência de indenização de guerra ao rei, pois não fora D. João IV quem ordenara o "levantamento da terra" contra os holandeses. A rebelião havia sido iniciativa dos moradores em "boa consciência". Tão boa consciência quanto a que os mesmos holandeses haviam mostrado, ao se rebelarem contra a tirania dos castelhanos, como eles gostavam de repetir. De modo que, se a revolta dos holandeses contra a Espanha havia sido justa, também o era a rebelião movida pelos luso-brasileiros contra a Holanda.

Manoel de Moraes retomou o argumento usado à farta pelos embaixadores de D. João IV em Haia, a saber, o de que os holandeses haviam conquistado aquelas partes do Brasil no tempo em que Portugal era cativo de Castela. Cativeiro injusto, pois a legítima sucessão, em 1580, cabia à Casa de Bragança (e nisto Manoel de Moraes repetiu um dos argumentos de seu texto

${ }^{2}$ Evaldo Cabral de Mello, O negócio do Brasil: Portugal, os Países Baixos e o Nordeste, 16411669, 3.ed. revista, Rio de Janeiro, Topbooks, 2003, p.143. 
pró-restauração de 1641). Quase deu vivas, ao saudar o "Duque de Bragança, hoje por graça de Deus, o poderoso monarca El Rei D. João, o quarto, nosso senhor". E se os holandeses alegassem, como alegavam, que a insurreição feria a trégua estabelecida em 1641, valia lembrar que foram eles os primeiros a rompê-la, tomando Angola, São Tomé e o Maranhão.

Manoel de Moraes também pôs em xeque a superioridade militar holandesa, inclusive a naval, embora admitisse que o inimigo tinha mais navios. Mas a madeira usada nos navios portugueses era melhor, ajuizou. Quanto ao combate em campo raso, os holandeses eram, segundo ele, um desastre. Ilustrou seu argumento citando a batalha do Monte das Tabocas, de que ele mesmo havia participado; a vitória facílima dos portugueses no Maranhão, em 1643; o fracasso de Nassau na Bahia, em 1638; o triunfo de Salvador Correa de Sá em Angola, em 1648. Aos holandeses, de fato, só restava a posse de Olinda e do Recife no início de 1649.

Não havia razão nenhuma, segundo o ex-jesuíta, para o rei restituir-lhes território que, de armas na mão, os "libertadores da pátria” haviam restaurado. E maior injustiça seria, escreveu Manoel, entregar aos hereges os moradores que "levantaram a terra" contra a tirania holandesa. Esta sim, crudelíssima, como estavam a comprovar os massacres no Rio Grande (Cunhaú e Uruaçú, 1645), onde foram os holandeses aliados aos "bárbaros tapuias" e ao "bárbaro potiguar”, perpetrando o assassinato de párocos, a profanação de igrejas e o estupro de matronas e donzelas.

Manoel de Moraes fez o seu parecer. Tinha larga experiência em assuntos holandeses, pois vivera oito anos em Harderwijk, Leiden e Amsterdã, a serviço da Companhia das Índias Ocidentais, antes de regressar a Pernambuco, como contratador de pau-brasil. Era ex-jesuíta, expulso da Companhia de Jesus por ter se passado aos holandeses, em 1635, razão pela qual seria preso e processado pela Inquisição, acusado de calvinismo. Quando escreveu seu parecer, tinha saído há poucos meses no auto-de-fé celebrado no Terreiro do Paço, vestindo hábito penitencial com insígnias de fogo. Estava nas últimas, mas arrependido de seus erros passados, e na expectativa de, quem sabe, ser recrutado como conselheiro do rei ou capitão nas guerras pernambucanas. Tudo, é claro, em troca de alguma modesta mercê. ${ }^{3}$

Manoel estava nas últimas, mas Portugal nunca tinha estado tão bem, pelo menos na guerra pernambucana, graças ao esforço dos restauradores lide-

${ }^{3}$ Ronaldo Vainfas, Traição: um jesuita a serviço do Brasil holandês processado pela Inquisição, São Paulo, Companhia das Letras, 2008. 
rados por João Fernandes Vieira, ele mesmo ex-sócio dos holandeses no tempo de Nassau. ${ }^{4} \mathrm{O}$ mestre-de-campo tinha começado a vida como feitor do engenho do holandês Jacob Stachouwer, de quem se tornaria sócio e procurador, em 1638. Pouco a pouco, graças à sua crescente proximidade com Maurício de Nassau, adquiriu terras e engenhos dentre os confiscados aos principais da resistência e postos em leilão. Tornou-se um dos mais ricos senhores de Pernambuco, além de membro da Câmara dos Escabinos da Cidade Maurícia, entre outros privilégios. Sua riqueza alcançou nada menos do que cinco engenhos, imensa escravaria, bois, cavalos, canaviais, joias, tudo graças ao largo crédito que lhe concedeu a WIC. As cifras mencionadas nos documentos em que João Fernandes tentou negociar suas dívidas são espantosas: cerca de 300 mil florins foi o que chegou a dever a particulares e à própria Companhia. Era o segundo maior devedor da WIC, quando assumiu a liderança dos insurretos.

A guerra liderada por João Fernandes colheu vitórias decisivas, de 1645 a 1649. As duas batalhas dos Guararapes, em especial, travadas entre abril de 1648 e fevereiro de 1649, confinaram os holandeses em Olinda e Recife. O mais estava perdido. Entrementes, em agosto de 1648, Salvador Correia de Sá tinha reconquistado Angola, partindo do Rio de Janeiro. O império holandês na África e no Brasil estava ferido de morte. ${ }^{5}$

Era mais fácil ser valentão nesta conjuntura do que nos começos da restauração, e valentões era como os adeptos de uma saída diplomática chamavam, pejorativamente, os defensores da guerra total contra a Holanda, sem medir as consequências. Manoel de Moraes, no fim da vida, assumiu o papel de valentão. E, na verdade, Manoel sempre fora valentão, pois tinha mudado várias vezes de lado nesta guerra. Valentão e temerário.

\section{Voltando a 1641: entre negociações e conspirações}

Nos começos da Restauração, porém, a situação de Portugal era periclitante. O próprio Manoel de Moraes, quando estava na Holanda, teve a oportunidade de acompanhar as primeiras negociações entre Portugal e os Estados Gerais dos Países Baixos. Corria o ano de 1641, a restauração portuguesa era ${ }^{4}$ José Antônio Gonsalves de Mello, João Fernandes Vieira: mestre-de-campo do terço de infantaria de Pernambuco (original de 1956), Lisboa, Centro de Estudos de História do Atlântico/ Comissão para as Comemorações dos Descobrimentos portugueses, 2000.

${ }^{5}$ Charles Boxer, Salvador de Sá e a luta pelo Brasile Angola, 1602-1886, São Paulo, Companhia Editora Nacional, 1973. 
recentíssima, a guerra contra a Espanha estava deflagrada. D.João IV enviou embaixador para Haia, a fim de negociar com os holandeses.

Estando em curso a Guerra dos Trinta Anos, e sendo a Holanda inimiga histórica da Espanha, contra a qual Portugal então lutava, os conselheiros de D. João IV julgaram razoável propor aos holandeses a devolução dos territórios que outrora pertenciam a Portugal, antes da União Ibérica. O embaixador Tristão de Mendonça Furtado chegou em Haia no início de 1641. Era homem de nobreza e de guerra, que tinha esposado a causa da restauração desde o início. Mas como diplomata era fraco ou pelo menos foi esta a impressão que dele ficou, em Portugal, por suas gestões em Haia.

O máximo que conseguiu foi assinar um tratado, em 12 de junho de 1641, em cujo artigo 24 os holandeses admitiam, vagamente, que os territórios do ultramar outrora portugueses poderiam ser objeto de futura partilha ou troca. Futuro incerto. Estabeleceram, ainda, nesse tratado, uma trégua de dez anos, fixando, porém, que, em caso de hostilidades, os súditos do Príncipe de Orange não poderiam ser levados à Inquisição por motivo de sua confissão religiosa. Portugal também cedeu neste ponto, e vale dizer que os tais súditos da Casa de Orange protegidos pelo acordo eram basicamente os judeus portugueses transferidos de Amsterdã para o Brasil. A sólida Talmud Torá, congregação dos judeus portugueses em Amsterdã, pressionou os Estados Gerais que, por sua vez, pressionaram o embaixador português, e até a isto se vergou a diplomacia portuguesa em 1641.

Quanto à trégua de dez anos, os holandeses a romperam no mesmo ano do tratado. Entre agosto e novembro de 1641, as armas de Maurício de Nassau conquistaram Angola, incluindo Luanda, Benguela e os portos satélites de São Tomé e Ano Bom. ${ }^{6}$ No mesmo mês de novembro, os holandeses tomaram o Maranhão. O domínio holandês no Brasil atingiu o apogeu, abarcando o território do Sergipe ao Maranhão, além do controle dos portos africanos essenciais para o tráfico de escravos. A colaboração das elites luso-brasileiras em Pernambuco, por sinal, nunca foi tão intensa como nessa época - tempo da chamada pax nassoviana.

É certo que os portugueses protestaram contra a violação do tratado de 1641, ato continuo à sua assinatura. Como resposta, ouviram dos delegados

\footnotetext{
${ }^{6}$ Sobre as conquistas holandesas na África, ver Luis Felipe de Alencastro, O trato dos viventes: formação do Brasil no Atlântico Sul, São Paulo, Companhia das Letras, cap. 6, p. 188-246; Klaas Ratelband, Os holandeses no Brasil e na costa africana: Angola, Kongo e São Tomé, 16001650, Lisboa, Vega, 2003, p. 109-145; Alberto da Costa e Silva, A manilha e o libambo: a África e a escravidão de 1500 a 1700, Rio de Janeiro, Nova Fronteira, 2002, p. 407-450.
} 
holandeses e zelandeses que a vigência do tratado dependia de sua ratificação pelo rei português. Como o rei tardou a ratificá-lo, e só o faria em 18 de novembro, os holandeses acharam por bem ampliar seus domínios ultramarinos o quanto antes. Agilidade da WIC, de um lado, e tardança portuguesa, de outro, porque em Lisboa este tratado era considerado muito desfavorável.

Tudo corria muito mal para os portugueses neste início da Restauração. Felipe IV se armava até os dentes para esmagar a rebelião portuguesa, embora estivesse às voltas com a revolta catalã. Não fosse a revolta da Catalunha e as coisas ficariam ainda piores para Portugal. Estava derrotado no ultramar, o império oriental esfrangalhado, e no Brasil também se perdera o Maranhão. E, mais grave, tinha perdido Angola. Um desastre. Até os mais fervorosos adeptos da Casa de Bragança consideravam difícil manter a soberania portuguesa sem recursos ultramarinos para combater a Espanha.

Não admira que a facção pró-hispânica da nobreza lusitana, por sinal muito numerosa, tenha tentado derrubar o rei, ainda em 1641, facilitando as coisas para Felipe IV. Afinal, boa parte dos fidalgos portugueses da "nobiliarquia grande" do reino mantinha-se fiel ao rei de Espanha. Vários deles se tinham estabelecido em Madri durante a União Ibérica e outros tantos se refugiaram na Espanha após a aclamação de D. João IV, por eles julgada um golpe de Estado. Felipe IV de Espanha buscava compensar generosamente tais lealdades com "mimos e promessas", certo de que tais homens seriam a base para a recuperação do reino rebelde. Em junho de 1641, o rei espanhol concedeu nada menos do que um título de marquês (Penalva) e quatro títulos de conde (Castelo Novo, Torres Vedras, Assentar e Vagos) a nobres fugidos de Portugal. Estes não tardaram a lançar Manifesto em favor do rei Felipe III de Portugal. ${ }^{7}$

Da lealdade a Felipe III à conjura contra D. João IV, o passo foi curto. Foi conspiração respeitável, cuja liderança foi atribuída a D. Luiz de Noronha e Menezes, marquês de Vila Real e primeiro conde de Caminha, títulos que herdara do irmão, D. Miguel Luiz de Menezes. A Casa de Vila Real era antiga, com titulação concedida ainda no início da dinastia de Avis e acrescida do ducado, no tempo de Felipe II de Espanha. O marquês de Vila Real era, sem dúvida, o nobre mais titulado entre os conjuradores, mas não foi o grande articulador do golpe contra D. João IV. Os grandes articuladores do golpe

\footnotetext{
${ }^{7}$ Fernando Bouza Alvarez, "Entre dois reinos, uma pátria rebelde. Fidalgos portugueses na monarquia hispânica depois de 1640", in: Portugal no tempo dos Filipes. Política, cultura, representações (1580-1668), Lisboa, Cosmos, 2000, p. 280-281.
} 
foram, antes de tudo, o arcebispo de Braga, portanto cardeal primaz do reino, D. Sebastião de Matos Noronha e Belchior Correia de Franca, fidalgo da Casa Real por serviços prestados em Tânger, Pedro Baeça da Silveira, tesoureiro da alfândega de Lisboa e cunhado de outro grande articulador, Diogo Brito Nabo, também fidalgo da Casa Real.

As articulações começaram ainda em dezembro de 1640 e se adensaram nos meses seguintes. Em julho de 1641, o grupo de conjurados já incluía Rui de Matos de Noronha, primeiro conde de Armamar; Nuno de Mendonça, segundo conde do Vale dos Reis; Antônio de Ataíde, segundo conde de Castanheira; Jorge de Mascarenhas, vedor da Casa Real no reinado de Filipe IV, filho de D. Jorge de Mascarenhas, marquês de Montalvão e ex-governador do Brasil; D. Agostinho Manuel de Vasconcelos, criado da Casa Real brigantina e até confidente de D. Teodósio, embora preferisse falar castelhano; João Soares de Alarcão, mestre-sala da Casa Real filipina; Gonçalo Pires de Carvalho e seu filho Lourenço Pires de Carvalho, provedor das obras reais; Antônio de Mendonça, comissário da Cruzada, frei Luis de Mello, bispo de Malaca, na Índia; Cristóvão Cogominho, guarda-mor da Torre do Tombo; Antônio Correia, oficial da Secretaria de Estado; Diogo de Brito Nabo, ex-alcaide de Ceuta, e Manuel Valente de Vilasboas, escrivão de Setúbal.

Enfim, para terminar, sem esgotá-la, a lista de conjurados, vale citar D. Francisco de Castro, ninguém menos do que o Inquisidor geral de Portugal, nomeado no tempo dos Filipes. ${ }^{8}$ A Inquisição era francamente filipina, tendo se fortalecido imensamente durante a União Ibérica. Basta dizer que o sobrinho de Felipe II de Espanha, o Cardeal-Arquiduque Alberto de Áustria foi, quase ao mesmo tempo, inquisidor geral e vice-rei de Portugal, entre 1583 e 1593. D. Pedro de Castilho foi também inquisidor geral e duas vezes vice-rei de Portugal, no reinado de Felipe III de Espanha (1598-1613). D. Miguel de Castro, por sua vez, além de arcebispo de Lisboa, pertencia aos quadros da Inquisição quando foi nomeado duas vezes presidente da Junta Governativa, instituição que substituiu pro tempore o Vice-Reinado, e terminou a carreira como deputado do Conselho Geral do Santo Ofício, órgão máximo da Inquisição portuguesa. Não é de surpreender, portanto, que a Inquisição tenha se aliado com a Casa de Habsburgo contra as pretensões brigantinas em 1640 e conspirado contra o rei em $1641 .^{9}$

\footnotetext{
${ }^{8}$ Leonor Freire Costa e Mafalda Soares da Cunha, D. João IV, Lisboa, Círculo de leitores, 2006, p. 114-117.

${ }^{9}$ Francisco Bethencourt, História das Inquisições, Lisboa, Círculo de Leitores, 1994, p. 111.
} 
Em 28 de julho de 1641, foi descoberta a conjura, cujo objetivo era enviar uma Jornada Real (filipina) desde Espanha até as fronteiras do reino, simultaneamente à deposição de D. João IV. Todos os nobres e fidalgos envolvidos na conspiração haviam obtido importantes mercês de Felipe IV de Espanha ou engrandecido as titulaturas, no caso de nobres de cepa antiga. Lideravam ou integravam, em posições estratégicas, importantes redes clientelares ligadas à Casa dos Habsburgos, temendo perder privilégios com a ascensão da nova dinastia em Portugal.

A repressão brigantina foi atroz, sobretudo contra os nobres e fidalgos. No caso do clero, o cardeal primaz D. Sebastião de Matos Noronha foi encarcerado na Torre de Belém, morrendo na prisão no mesmo ano de 1641. O inquisidor D. Francisco de Castro foi preso, porém libertado em 1643. Quatro nobres foram degolados em cerimônia pomposa realizada no Rossio, em Lisboa, no dia 29 de agosto de 1641. O primeiro a ser executado foi D. Luís de Noronha, marquês de Vila Real, e logo seu filho D. Miguel de Noronha, jovem de 27 anos que, na verdade, não tinha jogado papel importante na conjura. $\mathrm{O}$ conde de Armamar foi o terceiro degolado e, por fim, D. Agostinho Manuel, que custou a morrer porque o cutelo havia perdido o fio. As execuções prosseguiram na Rua dos Escudeiros, à frente do Palácio da Inquisição, com o enforcamento de dois fidalgos, Manuel Valente de Vilasboas e Diogo de Brito Nabo, que tiveram seus corpos esquartejados e as partes espalhadas pela cidade. No início de setembro, outros dois fidalgos tiveram destino semelhante. ${ }^{10}$

\section{2-1645: da negociação à insurreição}

Ao final de 1641, além da Restauração ter sido frontalmente contestada, Portugal caminhava mal nas chamadas "pazes com Holanda”. Ruim com o tratado, pior sem ele. Os portugueses nunca haviam perdido tanto no Atlântico, nem no tempo da União Ibérica, apesar dela. Tristão de Mendonça Furtado foi removido do posto e não tardou a morrer, sem nenhuma glória. Foi substituído por Francisco de Andrade Leitão, o mesmo que achou linda a mulher holandesa de Manoel de Moraes. Era diplomata de carreira do Portugal restaurado, desembargador da Casa de Suplicação, servira na Suécia, na França de Richelieu, e representou Portugal nas negociações de Munster, que puseram fim à Guerra dos Trinta Anos. Tinha fama de intransigente e era disso que Portugal precisava.

${ }^{10}$ Leonor Freire Costa e Mafalda Soares da Cunha, D. João IV, Lisboa, Círculo de Leitores, 2006, p. 127. 
Francisco de Andrade Leitão chegou em Haia, em 1642, fazendo jogo duro, denunciando nada menos que 13 violações do acordo de 1641, exigindo a pronta devolução dos territórios portugueses no Atlântico, a começar por Angola e pelo Maranhão, as últimas conquistas flamengas. Não conseguiu nada, salvo promessas ainda mais vagas, mas pelo menos fez com que as coisas ficassem claras. Os holandeses não tinham a menor intenção de devolver qualquer território aos portugueses, porque a Companhia das Índias tinha investido fortuna imensa nestas conquistas. Por qualquer devolução, por mínima que fosse, Portugal pagaria preço altíssimo: o sal de Setúbal, indenizações elevadas, privilégios comerciais aos holandeses no negócio do açúcar.

Francisco de Andrade Leitão foi deslocado para outras missões diplomáticas e substituído por Francisco de Souza Coutinho, embaixador realista e prudente. Sabia que o caso era de paciência e que as "pazes com Holanda" não dependiam de acordo bilateral de credibilidade duvidosa. Era preciso considerar o desfecho da Guerra dos Trinta Anos; aguardar se a Espanha reconheceria, enfim, a soberania dos Países Baixos calvinistas; examinar o avanço da guerra de Restauração contra a mesma Espanha; negociar o apoio do Papa Urbano VIII, que não reconhecia D. João IV como rei português, mas tampouco reconhecia o governo dos hereges holandeses; negociar com a França, que emergia como principal potência continental; aguardar o desfecho da guerra civil na Inglaterra, que mais tarde seria uma fiadora mais ou menos discreta da independência portuguesa.

Não por acaso, enquanto negociava com Holanda, Portugal multiplicou missões secretas a vários Estados, incluindo Roma, do que dá notícia detalhada Edgar Prestage no seu clássico As relações diplomáticas de Portugal com a França, Inglaterra e Holanda de 1640 a 1668.11 A prioridade máxima, para os diplomatas portugueses, era garantir a soberania dos Braganças, o que implicava guerra na península e diplomacia na Europa. O melhor do Oriente estava perdido. E talvez fosse preciso ceder boa parte do Brasil e da África, tudo pela independência recém-proclamada.

Francisco de Souza Coutinho foi embaixador em Haia, de 1644 a 1649, e constatou o que já se sabia em Lisboa. Os holandeses não estavam dispostos a ceder, embora o Brasil estivesse começando a dar prejuízo. E, para a Holanda, o Brasil era nada mais, nada menos, que um negócio da Companhia das Índias Ocidentais, a WIC. Na verdade, o comércio exportador do Brasil para a

${ }^{11}$ Edgar Prestage, As relações diplomáticas de Portugal com a França, Inglaterra e Holanda de 1640 a 1668, Coimbra, Imprensa Nacional, 1928, p. 196-197. 
Holanda atingiu seu auge justamente em 1642. A exportação de açúcar branco, por exemplo, que passava das 14 mil caixas, em 1641, caiu para menos de 11 mil, em 1643, e não passou de cerca de 8 mil, em 1644. Cairia ainda mais, de forma vertiginosa, nos anos seguintes. ${ }^{12} \mathrm{O}$ tráfico de escravos africanos, por outro lado, caminhava para o pico: cerca de 2 mil africanos foram vendidos no Brasil, em 1642; 4 mil, em 1643; 5 mil e tantos, em 1644. ${ }^{13}$

O quadro estrutural da crise estava dado: diminuição das exportações de açúcar, entre 1641 e 1644, e aumento do tráfico de escravos no mesmo período. Diminuição dos lucros da WIC, de um lado; aumento das dívidas dos produtores de açúcar, de outro. Dívidas que, por sinal, ou não eram pagas ou eram mal pagas. João Fernandes Vieira, como vimos, devia quase meio milhão de florins à WIC e a particulares holandeses, e não pagava nada ou pagava pouco.

A rebelião luso-brasileira em Pernambuco começou a ser urdida em 1644 e explodiu em 13 de junho de 1645, dia de Santo Antônio. Uma das primeiras medidas de João Fernandes foi decretar nulas as dívidas que os rebeldes tinham com os holandeses. Houve grande adesão da "nobreza da terra", entusiasmada com esta proclamação heroica. Nosso Manoel de Moraes foi um dos que aderiu, embora não pertencesse à tal nobreza, pois nesta altura explorava o pau-brasil sem pagar um tostão aos holandeses. Aderiu com fervor à revolta. Saiu à frente das tropas na batalha do Monte das Tabocas, em agosto de 1645, como capelão da guerra, crucifixo na mão, exortando a soldadesca a entoar a Salve Rainha. Pela Virgem Maria e por Santo Antônio, a insurreição pernambucana haveria de ser uma "guerra da liberdade divina", grande lema dos rebeldes.

\section{Paz declarada, guerra fingida: 1645-1649}

Vale inverter, nesta altura, o título do presente artigo, pois esta fórmula parece exprimir melhor o novo impasse estabelecido com a irrupção da "guerra da liberdade divina” em Pernambuco; isto porque, oficialmente, Portugal e Países Baixos estavam em paz, arrastando negociações diplomáticas, sendo que os portugueses custaram a admitir o estado beligerante dos luso-brasileiros, preferindo atribuir as "alterações pernambucanas" à insensatez de poucos

\footnotetext{
${ }^{12}$ Hermann Wätjen, O domínio colonial holandês no Brasil (original de 1938), 3. ed., Recife, Companhia Editora de Pernambuco, 2004, p. 494 e segs.

${ }^{13}$ Pedro Puntoni, A mísera sorte: a escravidão africana no Brasil holandês e as guerras no Atlântico Sul, São Paulo, Hucitec, 1999, p. 152.
} 
rebeldes. Fingia-se não haver a guerra que se travava no Brasil, ao menos enquanto esta farsa era possível de ser encenada.

Mas, no transcurso da rebelião, os endividados de Pernambuco haveriam de dar enorme ajuda à diplomacia portuguesa, ao deflagrarem a guerra restauradora. Diria mesmo que deram apoio crucial, a médio prazo, para a própria restauração no reino. Mas é claro que tais benefícios não seriam imediatos. Os holandeses protestaram muitíssimo contra a audácia da rebelião pernambucana e exigiram do embaixador português a imediata cessação das hostilidades e punição exemplar dos rebeldes. Neste ponto, a situação se inverteu. Francisco de Souza Coutinho prometia tudo aos holandeses, mas não fazia nada. O governador da Bahia, Antônio Teles da Silva, prometia mandar tropas para conter os rebeldes pernambucanos e, na verdade, enviava reforços para a rebelião.

O impasse durou alguns anos mais. Em 18 de setembro de 1645, por exemplo, com a capitulação holandesa no Forte Maurício, em Penedo, 200 prisioneiros de guerra foram enviados a Lisboa. Entre eles, seis judeus portugueses que, como súditos do Príncipe de Orange, estavam protegidos pelo acordo de 1641, e não podiam ser levados ao Santo Ofício. De nada valeu, outra vez, o acordo. D. Pedro da Silva e Sampaio, bispo da Bahia, mandou os presos para a Inquisição, do que resultou tremendo quiprocó diplomático.

Pressionados pela Talmud Torá de Amsterdã, os embaixadores holandeses exigiram a imediata liberação dos presos. D. João IV pressionou a Inquisição, sua inimiga, que teimou em não liberar nenhum deles. $\mathrm{O}$ rei escreveu duas vezes para os holandeses dizendo que nada podia fazer em matéria de fé, que era foro privativo da Inquisição, prometendo, no entanto, fazer o possível para libertá-los. Os Estados Gerais exigiram a libertação de todos, sem exceção. D. João IV conseguiu liberar a metade. Os outros três judeus que permaneceram presos saíram no auto-da-fé de dezembro de 1647, o mesmo, aliás, em que saiu o ex-jesuíta Manoel de Moraes; o mesmo auto em que foi queimado o jovem Isaque de Castro, biografado por Elias Lipiner, judeu corajoso que jamais recuou, chegando a dizer que a prosperidade da Holanda se devia a ter abrigado ali os judeus portugueses. Morreu queimado sem a misericórdia do garrote. ${ }^{14}$

\footnotetext{
${ }^{14}$ Alguns judeus portugueses vindos de Amsterdã ao Brasil foram entregues à Inquisição pelo bispo da Bahia em 1644 e 1645. O mais célebre deles foi o jovem Isaque de Castro, queimado em auto-de-fé realizado em dezembro de 1648. Ver Elias Lipiner, Isaque de Castro: o mancebo que veio preso do Brasil, Recife, Massangana, 1992.
} 
Antônio Vieira, principal assessor do embaixador Francisco de Souza Coutinho, e ele mesmo embaixador, era da mesma opinião que Isaque de Castro, mártir da comunidade judaico-portuguesa de Amsterdã. Vieira contestou frontalmente a Inquisição e, com isto, só fez acirrar o conflito entre jesuítas e inquisidores, bem como a oposição do Santo Ofício ao rei.

Mas, em matéria diplomática, Vieira era prudente e alinhava com Francisco de Souza Coutinho. Diante do avanço arrasador dos rebeldes pernambucanos nos Guararapes e da reconquista de Angola pelos portugueses, os holandeses ameaçaram entrar em guerra contra D. João IV. Estavam dispostos a bloquear Lisboa e até mesmo a se aliar com a Espanha. Inimiga histórica dos holandeses, a Espanha havia reconhecido, em 1648, a independência batava. O quadro era outro.

Ainda antes da segunda batalha dos Guararapes, em julho de 1648, Sousa Coutinho recebeu exigências duríssimas dos comissários dos Estados Gerais. Entre outras, a restituição de todos os territórios que possuía a WIC, em 1641, mais concessões territoriais na África e até a caução do morro de São Paulo, no litoral baiano; pesadas indenizações de guerra, incluindo o pagamento anual de mil caixas de açúcar, branco e mascavado, pelo prazo de dez anos; pagamento das dívidas que os colonos tinham com a WIC e particulares flamengos; neutralização de uma faixa de dez léguas na fronteira dos territórios holandeses, onde os portugueses não poderiam erigir fortificações.

Francisco de Sousa Coutinho amoleceu, apoiado em Antônio Vieira, e resguardando o desejo pessoal de D. João IV. O rei preferia pagar aos holandeses ou perder de vez suas ricas possessões no Atlântico do que se arriscar a perder a Coroa. De todo modo, o embaixador fez reparos pontuais às exigências holandesas, embora tenha concordado com o essencial delas, em documento firmado a 19 de agosto de 1648 .

Souza Coutinho e Vieira foram acusados de "Judas de Portugal" e de vendidos aos holandeses. Manoel de Moraes, embora alquebrado, acusou-os, sem citá-los, de "prendados dos holandeses"; logo ele, que tinha sido funcionário da WIC por oito anos! Manoel de Moraes, sempre atento às circunstâncias, apoiou os valentões liderados por Pedro Fernandes Monteiro, e pelo bispo de Elvas, D. Manoel da Cunha. Aos holandeses só restava fazer a guerra. 


\section{Soberania brigantina, império possível: o "Papel Forte" de Vieira}

Antônio Vieira defendeu a diplomacia portuguesa no célebre parecer conhecido como Papel Forte, no início de 1649, insistindo na entrega do Brasil. Nele, Vieira rebatia cada um dos argumentos esgrimidos pelos "valentões", sobretudo os do procurador da Fazenda Real, Pedro Monteiro Fernandes. No texto, distribuiu a matéria em quatro pontos, correspondentes, cada qual, a uma grande questão envolvida no debate.

No primeiro ponto, Vieira defendia o tratado firmado com os holandeses, refutando especialmente duas críticas dos "valentões". Quanto à crítica de que, cedendo Pernambuco aos holandeses, Portugal estaria abandonando seus vassalos aos hereges, Vieira alegou que nem por isso faltariam padres católicos para zelar pelo alimento espiritual dos fiéis, como alias tinha ocorrido durante a maior parte do domínio holandês na região. Quanto à crítica de que a capitulação portuguesa interromperia o trabalho de propagação da fé entre os índios, Vieira replicou alegando que, "já antes de lá irem os holandeses, não havia conversões nem propagações da fé por falta de gentios". As aldeias da região, prosseguia Vieira, eram de índios já cristãos e a maior parte deles tinha seguido Felipe Camarão no exílio baiano. ${ }^{15}$

Vieira estava certíssimo no primeiro ponto, pois o acordo firmado na Paraíba, em 1634, tinha garantido liberdade de consciência e de culto para os portugueses que permanecessem nas conquistas holandesas. Foi mesmo admitida pelo Conselho Político do Recife, órgão máximo da WIC no Brasil, a presença de clérigos seculares e religiosos de diversas ordens, com exceção dos jesuítas. O célebre frei Manuel Calado do Salvador, autor de $O$ valeroso Lucideno (1646), chegou a ser um dos interlocutores privilegiados, para não dizer amigo, de Maurício de Nassau. ${ }^{16}$

O mesmo não se pode dizer do argumento vieiriano relacionado à missionação. Antes de tudo porque havia grupos indígenas não catequizados, a exemplo dos tapuias, parte deles aliada dos holandeses na guerra pernambucana. Os tarairius, por exemplo, liderados pelo chefe Janduí, se destacaram no massacre de católicos perpetrado em Cunhaú e Uruaçú, no Rio Grande do

15 "Papel que fez o Padre Antônio Vieira a favor da entrega de Pernambuco aos holandeses", in: Alcir Pécora (org.), Escritos históricos e políticos do Padre Antônio Vieira, São Paulo, Martins Fontes, 1995, p. 338-341.

${ }^{16}$ José Antônio Gonsalves de Mello, Tempo dos flamengos: influência da ocupação holandesa na vida e na cultura do Norte do Brasil (original de 1947), 3. ed. aumentada, Recife, Massangana, 1987. 
Norte. ${ }^{17}$ Por outro lado, impossível desconhecer a cisão entre os potiguares: de um lado Felipe Camarão, de outro Pedro Poti, este último convertido ao calvinismo. A missionação calvinista junto aos índios potiguares e tabajaras tinha avançado bastante no período holandês, ${ }^{18} \mathrm{em}$ parte ancorada nos métodos da Companhia de Jesus. ${ }^{19}$ Um dos principais jesuítas da missionação pernambucana, o padre Manoel de Moraes, foi talvez o grande artífice desta tradução do jesuitismo para o calvinismo, ao se passar para o lado holandês no final de 1634. Foi Manoel de Moraes quem propôs o Plano para o bom governo dos indios ao conselho diretor da WIC, em Amsterdã, em grande parte adotado pela Igreja Reformada em Pernambuco. ${ }^{20}$

Antônio Vieira não poderia ignorar esses fatos, sobretudo porque as consequências da conquista holandesa, no tocante à religiosidade indígena, foram matéria de vasta correspondência jesuítica inclusa no Codice Brasile, depositado nos arquivos do Vaticano. De todo modo, se Vieira estava mal informado sobre o assunto, não tardaria a inteirar-se do problema como visitador da Companhia de Jesus nas partes do norte, nos anos 1550-1560. Chegaria a chamar a serra de Ibiapaba, no Ceará, de "Genebra dos sertões", tamanha era a aparente obstinação calvinista dos tabajaras ali refugiados.

Ainda na defesa do tratado, Vieira considerava que os insurretos se haviam rebelado por conta própria, sem consultar o monarca, de sorte que D. João IV não tinha nenhuma obrigação de socorrer os rebeldes. Ao argumento de que os rebeldes lutavam para erradicar a heresia da terra, Vieira replicou de modo implacável: os principais que moveram a guerra o fizeram "porque tinham tomado muito dinheiro aos holandeses e não puderam ou não o quiseram pagar". ${ }^{21}$ Não resta dúvida de que Vieira estava coberto de razão nesse ponto.

Na mesma linha de argumentação, Vieira condenou os pernambucanos por terem aberto nova frente de batalha, quando os portugueses já sofriam

${ }^{17}$ Erns van den Boogaart, "Infernal Allies: the Dutch West India Company and the Tarairiu - 1631-1654", in: J. M. Siegen et al (orgs.), A humanist prince in Europe and Brazil, The Hague: The Government Publishing Office, 1979, p. 519-538.

${ }^{18}$ Frans Leonard Shalkwijk, Igreja e Estado no Brasil holandês, Recife, FUNDARPE, 1986.

${ }^{19}$ Maria Aparecida Barreto Ribas, O leme espiritual do navio mercante: a missionação calvinista no Brasil holandês, tese de doutorado em História defendida na Universidade Federal Fluminense, Niterói, 2007.

${ }^{20}$ Ronaldo Vainfas, Traição: um jesuita a serviço do Brasil holandês processado pela Inquisição, São Paulo, Companhia das Letras, 2008, p. 120-121.

21 "Papel que fez o Padre Antônio Vieira...", p. 342. 
para sustentar a guerra contra a Espanha. Radicalizando sua oposição à revolta, desqualificou a tese de que holandeses deveriam restituir Pernambuco porque somente a tinham conquistado quando Portugal era dominado pela Espanha, inimigo comum de lusos e flamengos, além de questionar o direito português àquelas capitanias, unicamente com base na antiga concessão do papa (ratificada pelo Tratado de Tordesilhas). Adotando posição pragmática, afirmou sem rodeios que "o que dá ou tira os reinos do mundo é o direito das armas, cujas leis ou privilégios são mais largos; e segundo este direito, costumam capitular os príncipes quando um deles é menos poderoso". ${ }^{22}$ Estava convencido, nessa altura dos acontecimentos, de que os holandeses tinham mesmo algum direito às capitanias conquistadas no Brasil e o melhor seria reconhecê-lo.

Por outro lado, Vieira insistiu no fato de que "o levantamento da terra” tinha destruído boa parte da economia pernambucana, arruinado lavouras e engenhos. Se, antes da revolta, Pernambuco e demais capitanias da WIC produziam cerca de $1 / 3$ das riquezas do Brasil, embora ocupasse território não superior a $10 \%$ do território colonial, depois dela tudo se tinha reduzido à metade. Não seria grande dano ceder território tão arruinado aos flamengos, pensava Vieira, além do que, em pouco tempo não haveria mais recursos ou mantimentos para sustentar a guerra no Brasil. O melhor era ceder, como o próprio Vieira fizera no tratado acordado em Haia. Tudo o que se gastasse com indenizações e concessões aos holandeses, inclusive no tráfico de escravos angolanos, seria pouco em relação aos benefícios de que o reino poderia desfrutar. ${ }^{23}$

No segundo ponto do Papel Forte, dedicado a contraditar os meios propostos pelos "valentões" para inviabilizar a restituição de Pernambuco, Vieira põe em dúvida o pretexto de que os moradores de Pernambuco se recusavam a consentir nela, bem como o presumido perigo dos pernambucanos buscarem o apoio de outro príncipe na falta de socorro português. Tudo isso, segundo Vieira, não passava de falácia. Também julgava inviável, nessa altura, tentar comprar Pernambuco "por três ou quatro milhões de cruzados", simplesmente porque os holandeses não admitiam mais negociar com os portugueses em matéria territorial. Não confiavam na capacidade portuguesa de honrar a dívida. Não queriam perder as capitanias onde haviam investido tantos recursos. Não queriam ver manchada sua reputação internacional com

\footnotetext{
${ }^{22}$ Idem, p. 346.

${ }^{23}$ Idem, p. 349-354.
} 
tamanho vexame. ${ }^{24} \mathrm{~A}$ crise tinha chegado a tal ponto, segundo Vieira, que a única saída era aceitar o ultimatum holandês.

Isto posto, Vieira não teve dúvida em recomendar a restituição, ao invés da guerra, ao dissertar sobre o terceiro ponto de seu Papel Forte. Considerou que a WIC ainda era muito mais poderosa do que imaginavam os defensores da guerra e, se Portugal insistisse em desafiá-la, os Estados holandeses se aliariam à companhia de comércio para derrotar Portugal e conquistar o Brasil inteiro. Facilmente os holandeses fariam duas Armadas, uma para atacar a costa portuguesa, outra para tomar o Rio de Janeiro e a Bahia. ${ }^{25}$ Vieira realmente subestimava a capacidade de resistência dos luso-brasileiros e superestimava o poderio holandês. Parecia esquecer-se da resistência baiana em 1625, na célebre Jornada dos Vassalos, ou do fracasso da expedição contra a mesma Bahia, em 1638, comandada por Maurício de Nassau. A Bahia, por exemplo, tinha sempre resistido aos ataques holandeses. $\mathrm{E}$ os holandeses estavam praticamente reduzidos a Recife e Olinda em 1649.

Mas Vieira não estava interessado em valorizar as vitórias de uma guerra que condenava. Temia, sim, pela sorte de Portugal, exclusivamente empenhado em preservar a coroa de D. João IV. Seu grande receio era perder a guerra contra a Espanha, sobretudo se o reino fosse obrigado a enfrentar uma guerra marítima contra a Holanda. Utilizando sua brilhante retórica, Vieira afirmou: "O maior reino que tem hoje a Europa, mais rico e mais poderoso, mais unido e menos exposto a seus inimigos, é o de França; o menos rico, o menos poderoso e o mais dividido e mais exposto é o nosso; e é coisa muito para maravilhar que se não atreva França com Castela e Holanda, e que nos atrevamos nós". ${ }^{26}$

No quarto e último ponto, Vieira se dedica a enumerar com detalhes as fragilidades militares de Portugal, comentando as condições da Armada e o estado de 87 praças e fortalezas no Brasil, África e Ásia. Descontado o exagero derrotista, Vieira traçou excelente retrato da precariedade defensiva do império português. Neste particular, Vieira não se esqueceu das derrotas, como a da Armada do Conde da Torre, entre outros desastres militares. ${ }^{27}$

O parecer final que deu ao rei foi, portanto, favorável à entrega de Pernambuco, Paraíba, Itamaracá e Rio Grande do Norte aos holandeses, e mais

\footnotetext{
${ }^{24}$ Idem, p. 364-366.

${ }^{25}$ Idem, p. 367-368.

${ }^{26}$ Idem, p. 371.

${ }^{27}$ Idem, p. 379-398.
} 
o Sergipe, exceto uma terça parte dele a ser comprada por dinheiro. Além disso, apoiava o pagamento das dívidas que os moradores tinham contraído junto à WIC, assegurando ser possível renegociá-las em prazos mais largos ou com pagamentos em açúcar. Vieira também recomendava ceder na questão angolana, facilitando o tráfico de escravos para Pernambuco e admitindo que os holandeses erigissem fortaleza em Angola. ${ }^{28}$ Também os súditos do Príncipe de Orange, presos pelo Santo Ofício, deveriam ser libertados, se os houvesse, como exigiam os Estados Gerais.

No entender de Vieira, Portugal não tinha a menor condição de garantir sua soberania em face da Espanha e, ao mesmo tempo, enfrentar a Holanda nos mares. Não tinha homens, não tinha dinheiro, não tinha navios e, se escolhesse este caminho suicida, não teria juízo também. Mais sensato seria entregar Pernambuco e demais capitanias nordestinas aos holandeses e concentrar esforços na Bahia e capitanias do sul, sobretudo Rio de Janeiro. Vieira considerava que muito bem fariam os senhores pernambucanos ou paraibanos se migrassem para a Bahia ou para o Rio, levando consigo suas fazendas e seus escravos. Garantido o tráfico com Angola, dizia Vieira, esta parte da América continuaria a florescer para o bem de Portugal. Em termos estritamente políticos, Vieira parecia trabalhar com a noção de um "império possível" que nada lembra o Quinto Império por ele anunciado na sua obra providencialista. Estaria Vieira rascunhando, neste arrazoado, a ideia de um império colonial português centrado no Atlântico Sul?29

\section{O desfecho do imbróglio: nobreza da terra, henriques e camarões}

Poucas palavras para concluir, começando por dizer que este tremendo problema militar e diplomático não foi resolvido na corte portuguesa, entre pareceres e reuniões. Nem com o Papel Forte de Vieira, nem com o papel fraco de Manoel de Moraes.

Resolveu-o, em primeiro lugar, a Inglaterra de Cromwell, que declarou guerra à Holanda, em 1652, inviabilizando o esforço de guerra holandês em Pernambuco. Salvador Correia de Sá, em segundo lugar, deu também

\footnotetext{
${ }^{28}$ Idem, p.399-400.

${ }^{29}$ Quase um século depois, nas Instruções Inéditas a Marco António de Azevedo Coutinho, D. Luís da Cunha afirmou que, por ser "florentíssimo e bem povoado aquele imenso continente do Brasil", deveria o rei de Portugal tomar o título de "imperador do Ocidente", indo ali se estabelecer. E, disse mais, que "o lugar mais próprio para sua residência seria a cidade do Rio de Janeiro que, em pouco tempo, viria a ser mais opulenta que a de Lisboa”.
} 
contribuição enorme, ao reconquistar Luanda, Benguela e São Tomé, em 1648, retirando dos holandeses o controle do tráfico africano. E, por fim, os generais da insurreição pernambucana deram o golpe decisivo: João Fernandes Vieira, André Vidal de Negreiros e Martim Soares Moreno, pela nobreza da terra; Felipe Camarão, à frente dos índios potiguares, com o pomposo título de "governador geral de todos os índios do Brasil"; Henrique Dias, general do Terço negro, com seu título barroco de "governador dos negros, crioulos e mulatos do Brasil". A Insurreição Pernambucana fez pela restauração mais do que todos os diplomatas de D. João IV.

"Melhor guerra declarada do que paz fingida". Ao menos neste ponto, Manoel de Moraes, o renegado, tinha inteira razão, na sua "Reposta aos holandeses". 